\title{
An Empirical Analysis on the Country Differences Trade Effect Of China's Outward Foreign Direct Investment to 10 countries of EU based on the "One Belt and One Road"
}

\author{
Duan Zewen \\ School of Economics \\ Shanghai University \\ Shanghai, China \\ duanzewen@126.com
}

\begin{abstract}
Recently, EU is facing a severe financial crisis, the New Trade Protectionism occurs and blocks China's foreign trade to EU. At the same time, China's OFDI to EU has maintained upward trend. In order to dig deeper into the relationship of OFDI to $\mathrm{EU}$ and foreign trade, this paper cover the academic blank of this aspect.By using the panel data from 2003 to 2013 of China's OFDI stock and export \& import, this paper analyses the national differences of China's OFDI trade effect among 10 countries of EU: Britain ,Germany, France, Sweden, Holland ,Italy, Spain, Hungary, Poland, Denmark. The results indicate that while China's OFDI to Denmark turns out to be trade-replacing, China's OFDI to the rest of the 9 countries turns tradecreating. It's good for us to invest to the industries with local advantages based on the countries' different situations in EU and take full advantage of "One belt and One road".
\end{abstract}

Keywords- China ; 10 countries of EU ; OFDI ; trade effect;One belt and One road

\section{INTRODUCTION}

President Xi proposed a strategic idea to build "the silk road economic belt" and "the 21st century Maritime silk road" in 2013, which received a warm response from European Union. Due to the economic recession in EU, it occurs the New Trade Protectionism in the context of economical globalization, which blocks the development of bilateral trade liberalization. According to the foreign direct investment statistical bulletin, China's OFDI to EU has maintained the upward trend, and China's OFDI to EU has concentrated on the following 10 countries: Britain ,Germany, France, Sweden, Holland, Italy, Spain, Hungary, Poland, Denmark. The direct investment stock to EU has increased from 380.82 million in 2003 to 40.09661 billion in 2013. In terms of trade, China is EU's largest trading partner and the import goods to EU were nearly 72.05 billion in 2003 while the goods were 336.59 billion in 2013 .

There are differences in the industrial development and investment environment among EU countries, so does China's OFDI to EU substitute the bilateral trade or promote the bilateral trade? This paper has conducted the thorough research of China's OFDI to the representative 10 countries in EU, and try to tap potential, expand bilateral cooperation areas.

\section{LITERATURE REVIEW}

Robert Mundell[1] is the first one who advanced the substitution model towards the relationship between FDI and foreign trade. After that, Vernon[2] raised the product life cycle theory to support the substitution relationship between FDI and foreign trade. Kojima[3] put forward the opposite opinion that FDI and foreign trade are complementary. In the empirical research, Horst[4] analysed the relationship between United States FDI to Canada and exports to Canada, his conclusion was that tariff caused the FDI replace the foreign trade. Against that, Camarero and Tamarit[5] support FDI and foreign trade are complementary.

In China, Zhang Chunping[6] studied the relationship of China's OFDI and trade on classification. Liu Zaiqi, Xie Runde[7] analyzed the national differences of OFDI trade effect among ASEAN countries.HU Bing, Qiao Jing[8] examines the trade effect of OFDI stocks on exports in China by using dynamic panel data models and system GMM estimators.

After reviewing the existing literature, we can easily understand the fact that foreign scholars concentrated on the FDI of developed countries, and domestic scholars barely focused on China's FDI to developed countries especially EU. This article will cover the academic blank of this aspect.

\section{EMPIRICAL TEST}

\section{A. Research methods}

In the paper, we set export(EXO) and import(IMO) as dependent variables, set China's OFDI stock to each member of the chosen 10 countries as independent variables. The empirical model is as follows:

$$
\begin{aligned}
& \ln E X O_{i \mathrm{t}}=\alpha+\beta \ln F_{i t}+\varepsilon_{\text {eit }} \\
& \ln I M O_{i t}=\gamma+\delta \ln F_{i t}+\varepsilon_{i i t}
\end{aligned}
$$

In the empirical model, $\mathrm{i}$ represents each country, $\mathrm{t}$ represents observation period, $\varepsilon_{\text {eit }} 、 \varepsilon_{\text {iit }}$ represent random perturbed variables. $\beta$ represents the influence coefficient on export of FDI, $\delta$ represents the influence coefficient on import of FDI. 
First of all, use several unit root testing such as LLC、 IPS、 Fisher-ADF 、 Fisher-PP、 Breitung to verify the stability of panel data.

Then try to do cointegration test by using Pedroni test Kao test and Johansen Fisher test.

In the end, take advantage of the residual sum of squares to form $\mathrm{F}$ statistic.

$$
\begin{gathered}
F_{1}=\frac{(\mathrm{SE} 2-\mathrm{SE} 1) /[(\mathrm{N}-1) \mathrm{K}]}{S E 1 /[N T-N(K+1)]} \\
F_{2}=\frac{(\mathrm{SE} 3-\mathrm{SE} 1) /[(\mathrm{N}-1)(\mathrm{K}+1)]}{S E 1 /[N T-N(K+1)]}
\end{gathered}
$$

In this model, $\mathrm{N}=10, \mathrm{~T}=11, \mathrm{SE} 1$ represents the residual sum of squares of varying parameter model, SE2 represents the residual sum of squares of varying intercept model, SE3 the residual sum of squares of constant parameter model. If $F_{2}>F_{\alpha}[(\mathrm{N}-1)(\mathrm{K}+1), \mathrm{NT}-\mathrm{N}(\mathrm{K}+1)]$, the constant parameter model will not be chosen. Next if $F_{1}>F_{\alpha}[(\mathrm{N}-1) \mathrm{K}, \mathrm{NT}-\mathrm{N}(\mathrm{K}+1)]$, the varying parameter model will be chosen, if not, the varying intercept model will be chosen.

\section{B. Data Source}

We select 10 countries of EU, these countries are those which have close economic ties with China. The countries are Britain, Germany, France, Sweden, Holland, Italy, Spain, Hungary, Poland, Denmark. The data of FDI stock to EU come from < Statistical Bulletin of China's Outward Foreign Direct Investment>, the export data and import data are from <China Statistical Yearbook>. In the course of case study, the software of Eviews 7.2 is used to deal with the data.

\section{Empirical Results}

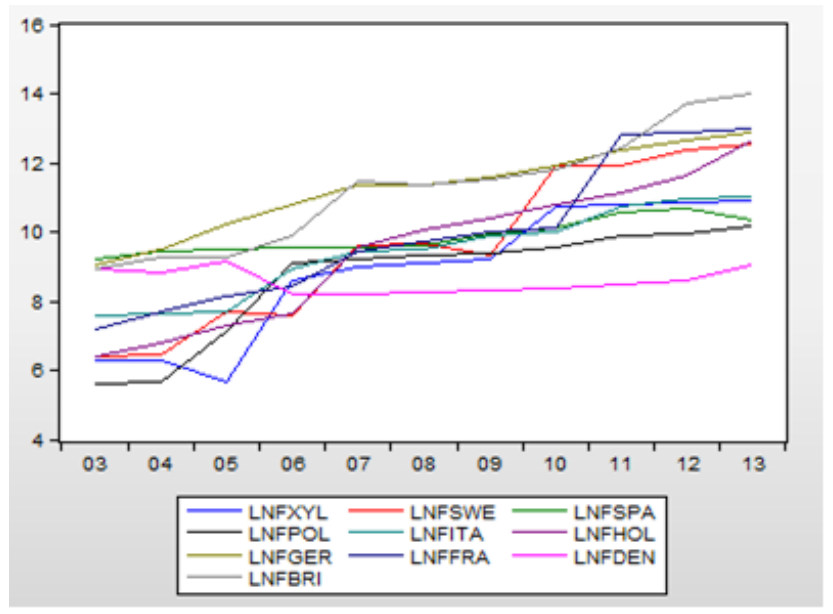

Figure 1. Sequence diagram of FDI stock

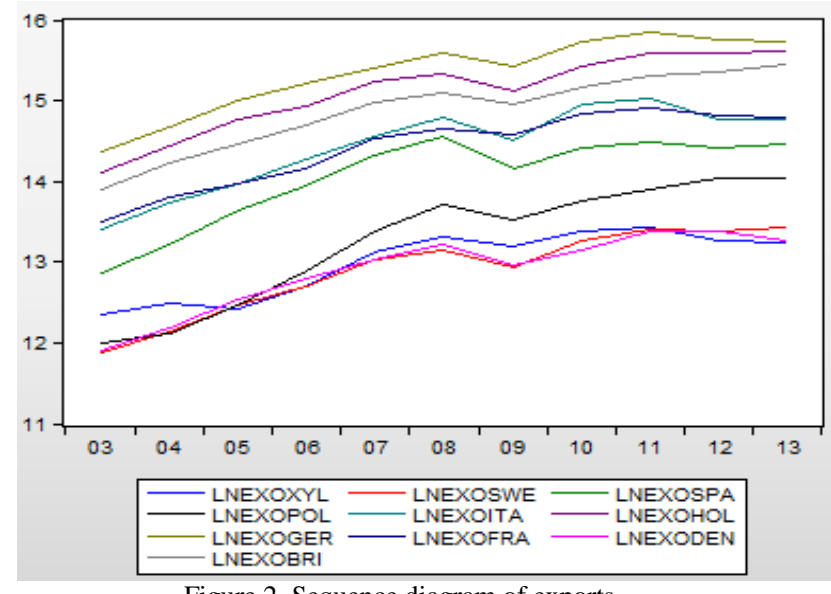

Figure 2. Sequence diagram of exports

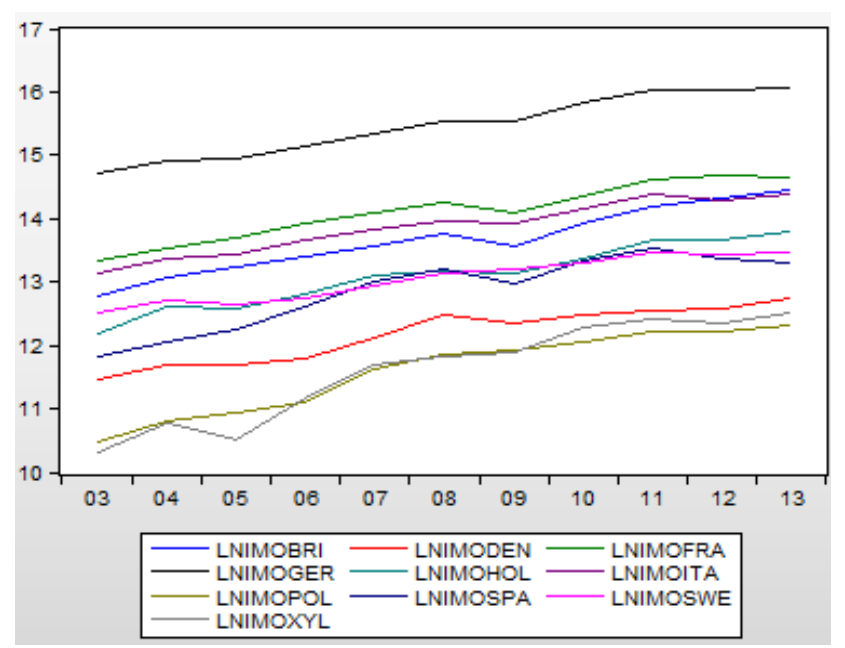

Figure 3. Sequence diagram of imports

\begin{tabular}{|c|c|c|c|c|c|c|c|}
\hline variable & LLC & Breitung & IPS & $\mathrm{ADF}$ & $\mathrm{PP}$ & Hadri & Test result \\
\hline $\ln \mathrm{F}$ & $\begin{array}{c}-5.31 \\
(0.00) \\
\end{array}$ & $\begin{array}{c}-0.79 \\
(0.22) \\
\end{array}$ & $\begin{array}{c}-0.63 \\
(0.26) \\
\end{array}$ & $\begin{array}{l}24.79 \\
(0.21) \\
\end{array}$ & $\begin{array}{r}27.36 \\
(0.13) \\
\end{array}$ & $\begin{array}{c}8.15 \\
(0.00) \\
\end{array}$ & \multirow{2}{*}{$\mathrm{I}(1)$} \\
\hline $\mathrm{DlnF}$ & $\begin{array}{c}-9.74 \\
(0.00) \\
\end{array}$ & $\begin{array}{c}-2.21 \\
(0.01) \\
\end{array}$ & $\begin{array}{c}-1.71 \\
(0.04) \\
\end{array}$ & $\begin{array}{l}44.79 \\
(0.00) \\
\end{array}$ & $\begin{array}{r}76.18 \\
(0.00) \\
\end{array}$ & $\begin{array}{l}25.25 \\
(0.00) \\
\end{array}$ & \\
\hline $\ln \mathrm{EXO}$ & $\begin{array}{c}-2.91 \\
(0.00)\end{array}$ & $\begin{array}{c}2.27 \\
(0.99)\end{array}$ & $\begin{array}{c}2.55 \\
(0.99)\end{array}$ & $\begin{array}{c}5.04 \\
(1.00)\end{array}$ & $\begin{array}{c}8.66 \\
(0.99)\end{array}$ & $\begin{array}{c}6.97 \\
(0.00)\end{array}$ & $\mathrm{I}(1)$ \\
\hline
\end{tabular}

TABLE I. UNIT ROOT TEST OF PANEL DATA 


\begin{tabular}{c|c|c|c|c|c|c|c}
\hline \multirow{2}{*}{ DlnEXO } & -9.80 & -5.10 & -1.86 & 45.83 & 83.77 & 27.79 & \\
& $(0.00)$ & $(0.00)$ & $(0.03)$ & $(0.00)$ & $(0.00)$ & $(0.00)$ & \\
& -4.07 & -0.62 & 0.00 & 19.18 & 26.51 & 8.50 & \\
\multirow{2}{*}{$\ln I M O$} & $(0.00)$ & $(0.27)$ & $(0.50)$ & $(0.51)$ & $(0.15)$ & $(0.00)$ & \multirow{2}{*}{$\mathrm{I}(1)$} \\
& -14.27 & -5.25 & -2.50 & 55.23 & 81.05 & 26.74 & \\
\hline \multirow{2}{*}{ DlnIMO } & $(0.00)$ & $(0.00)$ & $(0.01)$ & $(0.00)$ & $(0.00)$ & $(0.00)$ & \\
\hline
\end{tabular}

TABLE II. COINTEGRATION TEST OF EXPORT PANEL DATA(LAG INETRVAL DETERMINED BY SIC CODE)

\begin{tabular}{|c|c|c|c|}
\hline methods & hypothesis & statistics & $\begin{array}{c}\text { Coefficient } \\
\text { (P value) }\end{array}$ \\
\hline Kao test & $\begin{array}{c}H_{0}: \text { No } \\
\text { cointegration } \\
\text { relationship } \\
(\rho=1) \\
\end{array}$ & $\mathrm{ADF}$ & $\begin{array}{l}-3.20 \\
(0.00)\end{array}$ \\
\hline \multirow{7}{*}{$\begin{array}{c}\text { Pedroni } \\
\text { test }\end{array}$} & \multirow{4}{*}{$\begin{array}{c}H_{0}: \rho_{i}=1 \\
H_{1}:\left(\rho_{i}=\rho\right)<1\end{array}$} & Panel v & $\begin{array}{c}0.65 \\
(0.26) \\
\end{array}$ \\
\hline & & Panel rho & $\begin{array}{c}0.09 \\
(0.54)\end{array}$ \\
\hline & & Panel PP & $\begin{array}{l}-1.55 \\
(0.06)\end{array}$ \\
\hline & & Panel ADF & $\begin{array}{l}-0.84 \\
(0.20) \\
\end{array}$ \\
\hline & \multirow{3}{*}{$\begin{array}{cc}H_{0}: & \rho_{i}=1 \\
H_{1}: & \left(\rho_{i}\right)<1\end{array}$} & Group rho & $\begin{array}{c}0.99 \\
(0.84) \\
\end{array}$ \\
\hline & & Group PP & $\begin{array}{l}-1.54 \\
(0.06) \\
\end{array}$ \\
\hline & & Group ADF & $\begin{array}{l}-0.33 \\
(0.37)\end{array}$ \\
\hline
\end{tabular}

TABLE III. COINTEGRATION TEST OF IMPORT PANEL DATA(LAG INETRVAL DETERMINED BY SIC CODE)

\begin{tabular}{|c|c|c|c|}
\hline $\begin{array}{c}\text { Test } \\
\text { method }\end{array}$ & Hypothesis & statistics & $\begin{array}{c}\text { Coefficient } \\
\text { (P value) }\end{array}$ \\
\hline Kao test & $\begin{array}{c}H_{0}: \text { No } \\
\text { cointegration } \\
\text { relationship } \\
(\rho=1)\end{array}$ & $\mathrm{ADF}$ & $\begin{array}{l}-1.72 \\
(0.04)\end{array}$ \\
\hline \multirow{7}{*}{$\begin{array}{c}\text { Pedroni } \\
\text { test }\end{array}$} & \multirow{4}{*}{$\begin{array}{c}H_{0}: \rho_{i}=1 \\
H_{1}: \quad\left(\rho_{i}=\rho\right)<1\end{array}$} & Panel v & $\begin{array}{c}4.82 \\
(0.00)\end{array}$ \\
\hline & & Panel rho & $\begin{array}{c}1.33 \\
(0.91)\end{array}$ \\
\hline & & Panel PP & $\begin{array}{l}-1.78 \\
(0.04)\end{array}$ \\
\hline & & Panel ADF & $\begin{array}{l}-2.03 \\
(0.02) \\
\end{array}$ \\
\hline & \multirow{3}{*}{$\begin{array}{c}H_{0}: \rho_{i}=1 \\
H_{1}: \quad\left(\rho_{i}\right)<1\end{array}$} & Group rho & $\begin{array}{c}2.29 \\
(0.99) \\
\end{array}$ \\
\hline & & Group PP & $\begin{array}{l}-3.79 \\
(0.00)\end{array}$ \\
\hline & & $\begin{array}{l}\text { Group } \\
\text { ADF }\end{array}$ & $\begin{array}{l}-2.47 \\
(0.01)\end{array}$ \\
\hline
\end{tabular}

After Hausman test, $\mathrm{P}$ value is 0.03 , so we reject the original hypothesis and choose the fixed effect.
TABLE IV. THE EXPORT REGRESSION RESULT

\begin{tabular}{c|c|c|c|c|c|c}
\hline Country & $\alpha$ & $\mathrm{t}$ & $\mathrm{p}$ & $\beta$ & $\mathrm{t}$ & $\mathrm{p}$ \\
\hline Spain & 6.23 & 3.73 & 0.00 & 0.79 & 4.68 & 0.00 \\
\hline Poland & 9.51 & 21.57 & 0.00 & 0.43 & 8.65 & 0.00 \\
\hline Germany & 11.22 & 14.85 & 0.00 & 0.37 & 5.48 & 0.00 \\
\hline Italy & 11.02 & 17.95 & 0.00 & 0.36 & 5.62 & 0.00 \\
\hline Britain & 11.87 & 21.47 & 0.00 & 0.27 & 5.49 & 0.00 \\
\hline Holland & 13.03 & 33.81 & 0.00 & 0.22 & 5.52 & 0.00 \\
\hline Sweden & 10.83 & 30.42 & 0.00 & 0.21 & 5.92 & 0.00 \\
\hline France & 12.46 & 30.83 & 0.00 & 0.20 & 4.93 & 0.00 \\
\hline Hungary & 11.25 & 29.05 & 0.00 & 0.20 & 4.59 & 0.00 \\
\hline Denmark & 18.28 & 8.92 & 0.00 & -0.63 & -2.63 & 0.01 \\
\hline Adjusted $R^{2}=0.93$ & \multicolumn{3}{|c}{$\mathrm{F}=82.11$} & $\mathrm{DW}=0.86$
\end{tabular}

Note: this paper rearranged $\alpha$ from the largest to the smallest

Similarly, after Hausman test, $\mathrm{P}$ value is 0.00 , so we reject the original hypothesis and choose the fixed effect. 
TABLE V. THE IMPORT REGRESSION RESULT

\begin{tabular}{c|c|l|l|l|l|l}
\hline Country & $\gamma$ & $\mathrm{t}$ & $\mathrm{p}$ & \multicolumn{1}{|c|}{$\delta$} & $\mathrm{t}$ & $\mathrm{p}$ \\
\hline Spain & 3.37 & 2.36 & 0.02 & 0.96 & 6.67 & 0.00 \\
\hline Hungary & 8.11 & 24.56 & 0.00 & 0.40 & 10.85 & 0.00 \\
\hline Germany & 11.21 & 17.40 & 0.00 & 0.38 & 6.63 & 0.00 \\
\hline Poland & 8.52 & 22.68 & 0.00 & 0.36 & 8.30 & 0.00 \\
\hline Italy & 10.90 & 20.84 & 0.00 & 0.32 & 5.72 & 0.00 \\
\hline Britain & 10.31 & 21.89 & 0.00 & 0.30 & 7.19 & 0.00 \\
\hline Holland & 10.86 & 33.07 & 0.00 & 0.24 & 6.99 & 0.00 \\
\hline France & 12.07 & 35.04 & 0.00 & 0.21 & 6.06 & 0.00 \\
\hline Sweden & 11.67 & 38.44 & 0.00 & 0.14 & 4.69 & 0.00 \\
\hline Denmark & 15.26 & 8.73 & 0.00 & -0.36 & -1.77 & 0.08 \\
\hline Adjusted $R^{2}=0.97$ & \multicolumn{5}{|c|}{$\mathrm{F}=168.35$} & $\mathrm{DW}=1.05$ \\
\hline
\end{tabular}

Note: this paper rearranged $\gamma$ from the largest to the smallest

\section{EMPIRICAL ANALYSIS}

By using the panel data from 2003 to 2013 of China's OFDI stock and export\&import, this paper analyses the national differences of China's OFDI trade effect among 10 countries of EU, The results indicate that while China's OFDI to Denmark turns out to be trade-replacing, China's OFDI to the rest of the 9 countries turns trade-creating. But the trade-creating effect is not significant, perhaps due to China's FDI stock to EU is less than that to ASEAN, and the FDI motivation is avoiding artificial trade barriers. From the view of region, we can infer from Table IV and Table V that China's OFDI to Denmark substitute bilateral trade, while China's OFDI to other 9 countries promote trade and cooperation. Among the 9 countries, Spain has the Spain has the most significant effect of export\&import, furthermore, the coefficient of export creation is bigger than that of import creation.

\section{CONCLUSIONS}

After digging deeper into the relationship of OFDI and trade, we would like to make the following proposals: The first is to encourage our entrepreneurs to invest to EU's high-tech fields and it's helpful to promote China's industrial transformation and change China's prospects to the outside world. The second proposal is that we ought to invest the industries with local advantages based on the countries' different situations in EU .for example, we can look for suitable investment opportunities to Spain's wind industry. Under the background of "one belt and one road", it's a better way for Chinese enterprises to go out and will surely contribute to trade growth. The last but not the least, further expanding the scope of OFDI, try not to over-focus on several certain countries, and finally deepen mutual reciprocity and mutual benefit in the economic and trade area.

\section{REFERENCES}

[1] Mundell R.A.. International Trade and Factor Mobility[J], American Economic Review,1957,47(3),pp1269-1278.

[2] Vernon R.,International Investment and International Trade in the Product Cycle[J]. Quarterly Journal of Economics, 1966(80),pp190207

[3] Kojima K..Direct Foreig Investment:Japanese Model versus American Model[M], New York:Praeger Publishers, 1978.

[4] Horst,T. The Industrial Composition of U.S. Export to The Canadian Market[J]. The American Economic Review,1972,62(12),pp37-45.

[5] Camarero,M.,Tamarit,C.. Estimating the knowledge-capital model of the multinational enterprise[J]. American Economic Review,2004,91(3),pp693-708.

[6] Zhang Chunping.A Study on the Effect of China's OFDI on International Trade[J].The Journal of Quantitative \& Technical Economics, 2012 (6), pp74-85.

[7] Liu Zaiqi,Xie Runde.A Study on the Country Differences Trade Effect of China's OFDI in ASEN[J].World Economy Studies,2014(6),pp80-86..

[8] Hu Bing,Qiao Jing.How Does China's OFDI Affect Its Exports?An Empirical Analysis Dynamic Panel Data Models and System GMM Estimators[J].Economic Management Journal,2013(4),pp1119.

[9] Randall M,Bernard Y,Zhao M.Y..Perspectives on China's outward foreign direct Investment[J].Journal of International Business Studies,2008(39)

[10] Ramasamy B,Yeung M,Laforet S. China's outward foreign direct investment:Location choice and firm ownership[J].Journal of World Business,2012,47(1),pp17-25.

[11] Wang C,Hong J,Kafouros M,et al.What drives outward FDI of Chinese firms?Testing the explanatory power of three theoretical frameworks[J].International Business Review,2012,21(3),pp425438. 